\title{
EFFECT OF FERTILIZATION ON B-D-GLUCAN CONTENT IN OAT GRAIN (AVENA SATIVA L.)
}

\author{
MICHAELA HAVRLENTOVÁ ${ }^{1 *}$, ANDREA HLINKOVÁ ${ }^{1,2}$, ALŽBETA ŽOFAJOVÁ ${ }^{1}$, \\ PETER KOVÁČIK ${ }^{3}$, DANIELA DVONČOVÁ ${ }^{1}$, LUBOMÍRA DEÁKOVÁ ${ }^{1}$
}

\author{
${ }^{1}$ Plant Production Research Center Piešt'any \\ ${ }^{2}$ University of SS. Cyril and Methodius in Trnava \\ ${ }^{3}$ Slovak University of Agriculture in Nitra
}

HAVRlentovÁ, M. - HLINKOVÁ, A. - ŽOfAJOVÁ, A. - KOVÁČIK, P. - DVONČOVÁ, D. - DEÁKOVÁ, L'.: Effect of fertilization on B-D-glucan content in oat grain (Avena sativa L.). Agriculture (Pol'nohospodárstvo), vol. 59, 2013, no. 3, pp. 111-119.

$\beta$-D-glucan is a soluble component of dietary fibre local-
ised in the cell walls of cereal grains, especially oat and
barley. This homopolysaccharide presents a wide spec-
trum of health-beneficial effects in human beings, and its
higher concentration in oats makes it an essential com-
ponent for human nutrition. Genetic and environmental
factors influence the content of $\beta$-D-glucan. Four oat
varieties (two naked and two hulled) were grown in ex-
perimental fields at Vígl'aš-Pstruša (Central Slovakia) in
two consecutive years ( 2007 and 2008). The experiment
included five fertilisation treatments with application of
nitrogen (N) (as ammonium nitrate with dolomite) before sowing, and with selenium ( $\mathrm{Se}$ ) at the end of the tilling period (in the form of sodium selenate). A higher average content of $\beta$-D-glucan and test weight were observed in naked oats, Avenuda and Detvan, compared with hulled Vendelin and Zvolen. By contrast, higher yield and thousand grains weight were detected in hulled oats. Fertilisation with $\mathrm{N}+\mathrm{Se}$ increased the content of $\beta$-D-glucan, but significantly only in hulled oat grains. The warmer and drier climate in the year 2007 did not influence the content of $\beta$-D-glucan in oats, but caused a significant increase in thousand grains weight and test weight in both oat varieties, as well as grain yield in naked oats.

Key words: $\beta$-D-glucan; oat; fertilisation; nitrogen; selenium; Avena

Oats has long been recognised as a cereal of superior nutritive value as the nutritional composition of the grain is very favourable for human health. Compared to other cereals, oats contains significantly higher amounts of essential amino and fatty acids, dietary fibre, and its soluble fraction, $\beta$-D-glucan, as well as other beneficial phytochemicals (tocopherols, avenanthramides and others). Oat also tolerates wet weather and acidic soil; it is relatively resistant to foliar diseases and requires less agro- chemical and fertiliser inputs, and its demand as being essential in human nutrition is increasing.

$\beta$-D-glucan, a homopolysaccharide of glucose units linked by both $\beta-(1-3)$ and $\beta-(1-4)$ linkages, is localised in aleurone and subaleurone layers of the cell walls of the endosperm and its surrounding tissues in selected Poales, such as oat and barley grains. Generally, oat contains $3-5 \%$ of the polysaccharide; however, naked oats has been shown to contain a higher amount (Havrlentová et al. 2008).

RNDr. Michaela Havrlentová, PhD. (*Corresponding author), RNDr. Andrea Hlinková, Ing. Alžbeta Žofajová, PhD., Ing. Daniela Dvončová, PhD., Mgr. Lubomíra Deáková, Plant Production Research Center, 92168 Piešt’any, Bratislavská cesta 122, Slovak Republic. E-mail: havrlentov@vurv.sk

RNDr. Andrea Hlinková, University of SS. Cyril and Methodius in Trnava, Faculty of Natural Sciences, Námestie J. Herdu 2, 917 01Trnava, Slovak Republic

Doc. Ing. Peter Kováčik, PhD. Slovak University of Agriculture in Nitra, Trieda A. Hlinku 2, 94901 Nitra, Slovak Republic 
Deficiency of dietary fibre causes gastrointestinal and cardiovascular diseases in human beings, and oat products with high $\beta$-D-glucan content have been used as one option for preventing such diseases. The role of this polysaccharide in reducing cholesterol levels and postprandial glucose has been documented in many works (Tosh et al. 2008; Liatis et al. 2009, and others); however, some publications have not confirmed these effects. Scavenge-ability of free radicals and supporting during excessive physical and mental stresses, as well as during the treatment with antibiotics, chemotherapy and radiotherapy, are other positive effects of cereal $\beta$-D-glucan. It is also an important activator of the immune system (Daou \& Zhang 2012). In food technology, it is used as a substitute for fat and, therefore, applied in the production of low-fat products (Konuklar et al. 2004). Due to its low molecular weight, $\beta$-D-glucan is easily incorporated into products and improves their sensory properties (Havrlentová et al. 2011).

In cereals, the function of $\beta$-D-glucan is in the transport and regulation of water in the cell wall during germination and dehydration (Guillon et al. 2004). This polysaccharide gets concentrated in areas where load-bearing stresses are predicted to occur, and its metabolism could be, to a great extent, responsible for the plant's responses to the environmental signals within a moderate, physiological range (Hoson 1998).

The variability of $\beta$-D-glucan content is controlled by both, genetic and environmental factors,

T a b

The meteorological characteristics of experimental place in the year 2007 and 2008

\begin{tabular}{|c|c|c|c|c|}
\hline Specification & April & May & June & July \\
\hline 50 years average of temperature $(1951-2000)\left[{ }^{\circ} \mathrm{C}\right]$ & 8.40 & 13.10 & 16.30 & 17.80 \\
\hline Average of temperature in $2007\left[{ }^{\circ} \mathrm{C}\right]$ & 10.54 & 15.14 & 18.47 & 19.97 \\
\hline Average of temperature in $2008\left[{ }^{\circ} \mathrm{C}\right]$ & 9.67 & 14.51 & 18.41 & 19.74 \\
\hline 50 years average of precipitation $(1954-2003)[\mathrm{mm}]$ & 46.70 & 63.90 & 85.20 & 75.60 \\
\hline Average of precipitation in 2007 [mm] & 0.80 & 95.80 & 106.50 & 20.30 \\
\hline Average of precipitation in 2008 [mm] & 36.30 & 64.20 & 59.40 & 117.50 \\
\hline
\end{tabular}

T a b 1 e 2

Fertilisation treatments

\begin{tabular}{|c|c|c|c|c|c|c|c|c|c|}
\hline \multirow{3}{*}{ 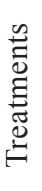 } & \multirow{3}{*}{$\begin{array}{l}\text { Mineral } \\
\text { compounds of } \\
\text { fertiliser }\end{array}$} & \multicolumn{8}{|c|}{ Rates of applied fertilisation } \\
\hline & & \multicolumn{4}{|c|}{ Year 2007} & \multicolumn{4}{|c|}{ Year 2008} \\
\hline & & $\begin{array}{c}\mathrm{N} \\
{[\mathrm{kg} / \mathrm{ha}]}\end{array}$ & $\begin{array}{c}\text { Se } \\
{[\mathrm{g} / \mathrm{ha}]}\end{array}$ & $\begin{array}{c}\mathrm{P} \\
{[\mathrm{kg} / \mathrm{ha}]}\end{array}$ & $\begin{array}{c}\mathrm{K} \\
{[\mathrm{kg} / \mathrm{ha}]}\end{array}$ & $\begin{array}{c}\mathrm{N} \\
{[\mathrm{kg} / \mathrm{ha}]}\end{array}$ & $\begin{array}{c}\mathrm{Se} \\
{[\mathrm{g} / \mathrm{ha}]}\end{array}$ & $\begin{array}{c}\mathrm{P} \\
{[\mathrm{kg} / \mathrm{ha}]}\end{array}$ & $\begin{array}{c}\mathrm{K} \\
{[\mathrm{kg} / \mathrm{ha}]}\end{array}$ \\
\hline 1 & PK & 0 & 0 & 24 & 96 & 0 & 0 & 12 & 96 \\
\hline 2 & $\mathrm{~N}_{1} \mathrm{PK}$ & 47 & 0 & 24 & 96 & 54 & 0 & 12 & 96 \\
\hline 3 & $\mathrm{~N}_{2} \mathrm{PK}$ & 35 & 0 & 24 & 96 & 40 & 0 & 12 & 96 \\
\hline 4 & $\mathrm{~N}_{1} \mathrm{PK}+\mathrm{Se}$ & 47 & $5 *$ & 24 & 96 & 54 & $5 *$ & 12 & 96 \\
\hline 5 & $\mathrm{~N}_{2} \mathrm{PK}+\mathrm{Se}$ & 35 & $5 *$ & 24 & 96 & 40 & $5 *$ & 12 & 96 \\
\hline
\end{tabular}

* $\mathrm{N}$ and Se applied at the end of tilling (BBCH 29) 
as well as their interaction. A dominant effect of genotype has been confirmed (Peterson et al. $1995)$; the heritability of $\beta$-D-glucan is controlled by the genetic systems of three to five effective factors and two to three dominant genes.

Nitrogen $(\mathrm{N})$ fertiliser has been shown to influence the level of biochemical constituents in the oat grain, although the principal effect of early application of $\mathrm{N}$ is to increase the crop yield. Higher $\mathrm{N}$ intake generally increases protein content (Michalík et al. 2007) and content of $\beta$-D-glucan in naked (Zhou et al. 2008) and common oats (Fan et al. 2009).

Selenium (Se) added to fertilisers is with the aim to increase the fertility of agricultural crops (agronomic biofortification) and for plant breeding (genetic biofortification). These two methods are supposed to be the most effective ways to increase Se intake in the population, whereby Se reaches different levels in the food chain (Hartikainen 2005). Plants are able to transform Se into many various low-molecular substances with similar values as essential vitamins (Whanger 2002).

The objective of this study was to evaluate the effect of fertilisation with $\mathrm{N}$ and/or Se on the content of $\beta$-D-glucan, grain yield, thousand grains weight, and testing of weight in naked and hulled oat grains.

\section{MATERIAL AND METHODS}

The field experiment with oat varieties, and treatments with various fertilisers was conducted in 2007 and 2008 by split-plot design as fully randomised blocks in four replications (plot size $10 \mathrm{~m}^{2}$, seeding rate of 5 million germinated grains per ha) at the Research and Breeding Station at Vígl'aš-Pstruša (Slovak Republic, SR).

The experiment was carried out in a potato growing area (altitude $375 \mathrm{~m}$ ) on pseudogley soil in central Slovakia which has a mean annual temperature of $7.6^{\circ} \mathrm{C}$ and a mean annual precipitation of $610 \mathrm{~mm}$. The average temperature and precipitation during the vegetation periods of 2007 and 2008 (April-July) are shown in Table 1.

Two naked - Avenuda (country of origin, Czech Republic, year of registration, 2001) and Detvan
(SR, 2002) and two hulled - Vendelin (SR, 2007) and Zvolen (SR, 1997) oat varieties were evaluated. Fertilisation treatment consisted of five courses with $\mathrm{N}$ and Se rates (Table 2). N, P and K were added according to the soil analysis for planned yield of 4 t/ha (Kováčik 1997). Treatments 2 and 4 dispensed with the same rate of $\mathrm{N}\left(\mathrm{N}_{1}\right)$ which was calculated according to the spring content of $\mathrm{N}_{\text {an }}$ at a depth of $0.0-0.3 \mathrm{~m}$, by $100 \%$ utilisation of $\mathrm{N}$ from the soil. In 2007, the rate of $\mathrm{N}\left(\mathrm{N}_{1}\right)$ applied prior to sowing was $47 \mathrm{~kg} / \mathrm{ha}$, and in 2008 it was $54 \mathrm{~kg} / \mathrm{ha}$. The rate of $\mathrm{N}\left(\mathrm{N}_{2}\right)$ in treatments 3 and 5 was calculated according to the amount of $\mathrm{N}_{\text {an }}$ at a depth of $0.0-0.6 \mathrm{~m}$ by $50 \%$ utilisation of $\mathrm{N}$ from the soil, that was $35 \mathrm{~kg} / \mathrm{ha}$ in 2007, and $40 \mathrm{~kg} / \mathrm{ha}$ in 2008 . Phosphorus (as hyperkorn 26\% $\mathrm{P}_{2} \mathrm{O}_{5}$ ) and potassium (as potassium salt $60 \% \mathrm{~K}_{2} 0$ ) were applied once, in the autumn. $\mathrm{N}$ was applied in the form of ammonium nitrate with dolomite $(27 \% \mathrm{~N})$ before seeding. Se $(5 \mathrm{~g} / \mathrm{ha}$, in the form of sodium selenate) was added at the end of tilling ( $\mathrm{BBCH}$ 29) using foliar application.

During vegetation, the critical and essential parameters of the crop were evaluated, and during the ripening phase, grain yield ( $\mathrm{t} / \mathrm{ha}$, calculated at $14 \%$ humidity), thousand grains weight $(\mathrm{g})$, test weight $(\mathrm{g})$, and $\beta$-D-glucan content (\%) were determined from each plot. $\beta$-D-glucan was measured by the enzymatic method 'Mixed-linkage beta-glucan assay procedure' from Megazyme International Ireland (McCleary 2006) in two parallel samples. Milled oat grains sifted through a $0.5 \mathrm{~mm}$ screen were suspended and hydrated in a sodium-phosphate buffer solution of $\mathrm{pH} 6.5$, and then incubated with purified lichenase enzyme and filtered. An aliquot of the filtrate was then hydrolysed to completion with purified $\beta$-glucosidase in a sodium-acetate buffer solution of $\mathrm{pH}$ 5.0. The resultant D-glucose was assayed using a glucose oxidase/peroxidase reagent. The polysaccharide's evaluations were calculated on a dry weight basis using Sartorius MA 45 (Sartorius AG, Göttingen/Germany).

Statistical analyses (analysis of variance, simple regression) were performed with the software package Statgraphics plus for Windows. 


\section{RESULTS AND DISCUSSION}

Analyses of variance showed that the oat type (hulled or naked) caused the greatest source of variability from the evaluated factors $(57.6 \%$ portion in $\beta$-D-glucan, $77.3 \%$ in grain yield, $86.3 \%$ in thousand grains weight and $63.1 \%$ in test weight). Therefore, characteristics were analysed separately for hulled (Table 3) and naked (Table 4) oats.

Year of cultivation did not significantly affect the content of $\beta$-D-glucan in either of the evaluated va- rieties of oats. In 2008 , the content of $\beta$-D-glucan was higher than it was in 2007; in naked oats, the difference was $4.1 \%$, and in hulled oats, it was $1.8 \%$ higher in 2008 than it was in 2007 (Table 5). Because of the higher precipitation in 2008 (by $54 \mathrm{~mm}$ ), and lower average temperature (by $0.45^{\circ} \mathrm{C}$ ) compared with 2007 (Table 1), this observation was unexpected. Higher precipitation and lower temperatures during the flowering period and grain formation period in naked barley grains, caused negative effects on the content of $\beta$-D-glucan (Ehrenbergerová et

T

Mean squares from analysis of variance of evaluated traits: hulled oats

\begin{tabular}{|c|c|c|c|c|c|}
\hline Source & $d f$ & ß-D-glucan & Grain yield & $\begin{array}{c}\text { Thousand grains } \\
\text { weight }\end{array}$ & Test weight \\
\hline A: year & 1 & 0.085 & 0.026 & $308.112^{++}$ & $25.425^{++}$ \\
\hline B: fertilisation & 4 & $0.509^{++}$ & 0.250 & 1.941 & 1.135 \\
\hline C: variety & 1 & 0.093 & $10.552^{++}$ & $12.013^{+}$ & $12.800^{++}$ \\
\hline $\mathrm{AB}$ & 4 & 0.277 & 0.182 & 3.691 & 0.167 \\
\hline $\mathrm{AC}$ & 1 & $0.636^{+}$ & $9.705^{++}$ & $7.813^{+}$ & 0.421 \\
\hline $\mathrm{BC}$ & 4 & $0.614^{++}$ & 0.128 & 2.716 & 0.718 \\
\hline $\mathrm{ABC}$ & 4 & $0.626^{++}$ & 0.200 & 4.141 & 2.201 \\
\hline Residual & 60 & 0.112 & 0.107 & 1.942 & 0.997 \\
\hline Total & 79 & & & & \\
\hline
\end{tabular}

${ }^{++} P \leq 0.01 ;{ }^{+} P \leq 0.05 ; d f-$ Degree of freedom

T a b 1 e 4

Mean squares from analysis of variance of evaluated traits: naked oats

\begin{tabular}{|c|c|c|c|c|c|}
\hline Source & $d f$ & B-D-glucan & Grain yield & $\begin{array}{c}\text { Thousand grains } \\
\text { weight }\end{array}$ & Test weight \\
\hline A: year & 1 & 0.774 & $14.882^{++}$ & $143.113^{++}$ & $1298.060^{++}$ \\
\hline B: fertilisation & 4 & 0.445 & $0.422^{++}$ & 1.394 & 1.070 \\
\hline C: variety & 1 & $14.680^{++}$ & $11.618^{++}$ & $94.613^{++}$ & $43.145^{++}$ \\
\hline AB & 4 & 0.617 & 0.260 & 1.081 & 0.925 \\
\hline $\mathrm{AC}$ & 1 & 0.088 & 0.069 & 0.013 & 0.007 \\
\hline $\mathrm{BC}$ & 4 & 0.113 & 0.119 & 3.081 & 1.676 \\
\hline $\mathrm{ABC}$ & 4 & 0.206 & 0.188 & 0.669 & 3.138 \\
\hline Residual & 60 & 0.267 & 0.104 & 1.579 & 0.657 \\
\hline Total & 79 & & & & \\
\hline
\end{tabular}

${ }^{++} P \leq 0.01 ;{ }^{+} P \leq 0.05 ; d f-$ Degree of freedom 
al. 2008). Also, Saastamoinen et al. (2004) evaluated the effect of temperature and precipitation on the content of $\beta$-D-glucan in Finnish oat varieties, and detected that the average content of this polysaccharide during a cold and rainy year was significantly lower compared to that obtained during a dry and hot year. Similar results were also observed by Ehrenbergerová et al. (2008) by evaluating spring waxy barley seeds for human consumption. Also, in malt barley, Zhang et al. (2001) recognised a significantly negative effect of higher precipitation during the growth and, on the other hand, positive effect of higher temperature $\left(25-30^{\circ} \mathrm{C}\right)$ on $\beta$-D-glucan content.

Fertilisation significantly influenced the content of $\beta$-D-glucan in hulled oats (Table 3 ) and in naked oats, by variety (Table 4). The influence was higher in naked oats compared to the hulled type, by $39.9 \%$ (Table 5). Our results have been communicated to other authors (Havrlentová et al. 2008; Andersson \& Börjesdolter 2011; and others). Higher nutritional quality in naked oats was also described by Michalík et al. (2007). In naked oats, significant differences were detected among oat varieties, where Avenuda yielded $0.86 \%$ higher $\beta$-D-glucan content compared with Detvan (Table 6). Significant effects of genotype and growing conditions were also confirmed in a European oats programme in which the $\beta$-D-glucan content was analysed in a representative set of 165 oat genotypes (Redaelli et al. 2013). Many authors indicate a wide genetic variability for $\beta$-D-glucan content in oat grain which can be used in creat-

$\mathrm{T} \quad \mathrm{a} \quad \mathrm{b} \quad 1 \quad \mathrm{e} \quad 5$

Average values of oat traits according to years of growing

\begin{tabular}{|l|c|c|c|c|c|c|c|c|}
\hline \multirow{3}{*}{ Year } & \multicolumn{2}{|c|}{$\begin{array}{c}\text { B-D-glucan } \\
{[\%]}\end{array}$} & \multicolumn{2}{c|}{$\begin{array}{c}\text { Grain yield } \\
{[\mathrm{t} / \mathrm{ha}]}\end{array}$} & \multicolumn{2}{c|}{$\begin{array}{c}\text { Thousand grains weight } \\
{[\mathrm{g}]}\end{array}$} & \multicolumn{2}{c|}{$\begin{array}{c}\text { Test weight } \\
{[\mathrm{g}]}\end{array}$} \\
\cline { 2 - 9 } & Hulled & Naked & Hulled & Naked & Hulled & Naked & Hulled & Naked \\
\hline 2007 & 3.35 & 4.63 & 6.72 & $4.78^{\mathrm{b}}$ & $38.12^{\mathrm{b}}$ & $25.92^{\mathrm{b}}$ & $52.55^{\mathrm{b}}$ & $69.37^{\mathrm{b}}$ \\
2008 & 3.41 & 4.82 & 6.75 & $3.92^{\mathrm{a}}$ & $34.20^{\mathrm{a}}$ & $23.25^{\mathrm{a}}$ & $51.43^{\mathrm{a}}$ & $61.32^{\mathrm{a}}$ \\
$L S D_{0.05}$ & - & - & - & 0.144 & 0.623 & 0.562 & 0.446 & 0.362 \\
$\bar{x}$ & 3.38 & 4.73 & 6.74 & 4.35 & 36.16 & 24.59 & 51.99 & 65.35 \\
\hline
\end{tabular}

LSD - Least significant difference; $\bar{x}$-Arithmetic mean

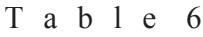

Average values of oat traits analyzed in two years and on five fertilization treatments according to varieties

\begin{tabular}{|l|c|c|c|c|}
\hline Variety & $\begin{array}{c}\text { B-D-glucan } \\
{[\%]}\end{array}$ & $\begin{array}{c}\text { Grain yield } \\
{[\mathrm{t} / \mathrm{ha}]}\end{array}$ & $\begin{array}{c}\text { Thousand grains } \\
\text { weight }[\mathrm{g}]\end{array}$ & $\begin{array}{c}\text { Test weight } \\
{[\mathrm{g}]}\end{array}$ \\
\hline Vendelin & 3.34 & $7.10^{\mathrm{b}}$ & $36.55^{\mathrm{b}}$ & $51.59^{\mathrm{a}}$ \\
Zvolen & 3.41 & $6.38^{\mathrm{a}}$ & $35.78^{\mathrm{a}}$ & $52.39^{\mathrm{b}}$ \\
$L S D_{0.05}$ & - & 0.146 & 0.623 & 0.446 \\
Avenuda & $5.16^{\mathrm{b}}$ & $4.73^{\mathrm{b}}$ & $25.68^{\mathrm{b}}$ & $64.61^{\mathrm{a}}$ \\
Detvan & $4.30^{\mathrm{a}}$ & $3.97^{\mathrm{a}}$ & $23.50^{\mathrm{a}}$ & $66.08^{\mathrm{b}}$ \\
$L S D_{0.05}$ & 0.231 & 0.144 & 0.562 & 0.362 \\
\hline
\end{tabular}

$L S D$ - Least significant difference

Different letters within the same column of each trait indicate significant differences at $P \leq 0.05$ 
ing new varieties containing the desired $\beta$-D-glucan content. Many breeders try to combine a high level of $\beta$-D-glucan with a high protein content and low lipid content in oat grain. On the other hand, by using oat grain as a feed grain, higher protein and lipid content and low $\beta$-D-glucan content are desirable.

In hulled oats, higher rates of $\mathrm{N}$ (treatments 2 and 3) did not increase the $\beta$-D-glucan content compared to the control treatment without the addition of $\mathrm{N}$ in the fertiliser (treatment 1) (Table 7). Our results are in accordance with Humphreys et al. (1994) who did not observe any effects of $\mathrm{N}$ on $\beta$-D-glucan content. May et al. (2004) stated that application of $\mathrm{N}$ together with delayed sowing caused changes in protein, lipid and $\beta$-D-glucan content in oat and barley. Delayed and earlier sowing resulted in higher $\beta$-D-glucan content, and delayed sowing reduced protein content. Earlier sowing also increased yield and thousand grains weight, what was detected by Zhao et al. (2008) by analysing Tibetan spring naked barley.

In our work, application of Se at the same rate of $\mathrm{N}$ (treatment 2 versus treatment 4 ; treatment 3 versus treatment 5 ) increased the $\beta$-D-glucan content in hulled oat by $12.6 \%$ and $5.8 \%$, respectively. The highest $\beta$-D-glucan content was observed with treatment 4 which was characterised by higher rates of $\mathrm{N}$ (47 kg N/ha in 2007, and $54 \mathrm{~kg} \mathrm{~N} / \mathrm{ha}$ in 2008 (Table $2)$ ), and also by addition of Se. By comparison with treatment 5 , the increase of $\beta$-D-glucan content was $5.20 \%$ in treatment 4. Similarly, Zhang et al. (2002) also observed that $\mathrm{N}$ fertiliser (135 kg/ha) significantly influenced the $\beta$-D-glucan content. Fan et al. (2009) also detected higher $\beta$-D-glucan content, as well as yield, thousand grains weight and protein content in oat genotypes. The accumulation rate of $\beta$-D-glucan was greater at the early stage of grain development, and reached a maximum around 25 days after anthesis (Fan et al. 2009). In naked oat, differences between $\beta$-D-glucan content after fertiliser application were not significant, and were in the range from $4.66 \%$ (treatments 1 and 2) to $4.92 \%$ (treatment 4 ). The highest $\beta$-D-glucan content was found in both oat varieties in treatment 4 .

Our results showed that $\mathrm{N}$ fertiliser with Se had a positive impact on higher $\beta$-D-glucan content in hulled oats. Zhou et al. (2008) found that enhanced intake of $\mathrm{N}$ plus phosphorus increased the content of $\beta$-D-glucan in naked oats, whereby, the highest $\beta$-D-glucan content was detected by $\mathrm{N}$ at the rate of $135 \mathrm{~kg} / \mathrm{ha}$ and $\mathrm{P}_{2} \mathrm{O}_{5} 90 \mathrm{~kg} / \mathrm{ha}$ per plot.

$\mathrm{Se}$, best acceptable in the form of $\mathrm{Na}_{2} \mathrm{Se}_{4}$ (Eurola et al. 1990), is primarily transported into the chloroplast. $\mathrm{Se}_{4}^{-2}$ then activates ATP-sulphurylase and forms the APSe by being reducing to selenite. This results in the production of amino acids, such as selenocysteine and selenomethionine. Selenium increases the content of amino acids, particularly isoleucine (Duma \& Karklina 2008). Selenomethionine can be methylated to dimethylselenid through evaporation in the plant. It is particularly difficult and not easy to determine the levels of Se in the plant,

T a b 1 e 7

Average values of oat traits of two hulled and two naked oats analyzed in two growing years according to fertilisation treatments

\begin{tabular}{|c|c|c|c|c|c|c|c|c|}
\hline \multirow{2}{*}{$\begin{array}{c}\text { Fertilisation } \\
\text { treatment }\end{array}$} & \multicolumn{2}{|c|}{$\begin{array}{c}\text { B-D-glucan } \\
{[\%]}\end{array}$} & \multicolumn{2}{c|}{$\begin{array}{c}\text { Grain yield } \\
{[\mathrm{t} / \mathrm{ha}]}\end{array}$} & $\begin{array}{c}\text { Thousand grains weight } \\
{[\mathrm{g}]}\end{array}$ & \multicolumn{2}{c|}{$\begin{array}{c}\text { Test weight } \\
{[\mathrm{g}]}\end{array}$} \\
\cline { 2 - 10 } & Hulled & Naked & Hulled & Naked & Hulled & Naked & Hulled & Naked \\
\hline 1 & $3.27^{\mathrm{a}}$ & 4.66 & 6.55 & $4.17^{\mathrm{a}}$ & 36.59 & 24.75 & 52.40 & 65.62 \\
2 & $3.25^{\mathrm{a}}$ & 4.66 & 6.85 & $4.18^{\mathrm{ab}}$ & 36.03 & 25.0 & 52.03 & 65.24 \\
3 & $3.28^{\mathrm{a}}$ & 4.53 & 6.73 & $4.41^{\mathrm{bc}}$ & 36.47 & 24.31 & 52.02 & 65.63 \\
4 & $3.66^{\mathrm{b}}$ & 4.92 & 6.72 & $4.47^{\mathrm{c}}$ & 35.81 & 24.56 & 51.75 & 65.12 \\
5 & $3.47^{\mathrm{ab}}$ & 4.89 & 6.85 & $4.52^{\mathrm{c}}$ & 35.91 & 24.31 & 51.76 & 65.13 \\
LSD $_{0.05}$ & 0.236 & - & - & 0.227 & - & - & - & - \\
\hline
\end{tabular}

$L S D$ - Least significant difference

Different letters within the same column of each trait indicate significant differences at $P \leq 0.05$ 
and to determine whether Se is essential for plant microelements. However, there is evidence that a higher content of Se (depending on the concentration of sulphur) has a positive impact, not only on levels of amino acids, but also on plant growth and multiplication (Pennanen et al. 2002).

The effect of Se on the content of $\beta$-D-glucan has not been proven till now. It can only by assumed that due to a high positive correlation between protein and $\beta$-D-glucan in oat grain (Havrlentová et al. 2008 ), increased protein content can also result in increased $\beta$-D-glucan content. Se can probably affect the biosynthesis of $\beta$-D-glucan in a positive manner. According to our results, $\mathrm{N}$ fertiliser supplemented with Se caused higher $\beta$-D-glucan levels in both, naked and hulled oat varieties, as shown earlier.

As expected, the mean grain yield in naked oats was lower by $35.5 \%$ compared with hulled oat grain. In hulled oats, the grain yield was influenced only by variety (Table 3 ), and Vendelin had a higher average grain yield (by $11.3 \%$ ) compared to Zvolen (Table 6). On the other hand, the year, fertiliser and the variety of oats showed statistically significant effects on grain yield in naked oat (Table 4). Higher average grain yield was observed in 2007 with higher average temperature and lower precipitation during the vegetation period (Table 1) compared to a 50 -year average and the year 2008. Between the two evaluated naked oat cultivars, the grain yield was higher in Avenuda (of $0.76 \mathrm{t} / \mathrm{ha}$, Table 6). Compared with the control treatment (treatment 1), all fertiliser treatments increased grain yield; however, in treatments 4 and 5 (combined rates of N, P, K and Se) the highest grain yield was achieved (Table 7). It is known that $\beta$-D-glucan and protein contents are negatively correlated with starch and yield (Oscarsson et al. 1998). Similarly, also in our research, a negative correlation between grain yield and the content of $\beta$-D-glucan $(r=-0.790)$ was detected.

In both oat groups, thousand grains weight and test weight were influenced by year of cultivation and variety of oats (Tables 3 and 4). Thousand grains weight was higher in hulled oats (Table 5 ), and in the hulled cultivar, Vendelin (Table 6). Higher thousand grains weight was detected in both oat types in the year 2007 (Table 5). On the contrary, test weight was higher in naked oats, and the differ- ence between naked and hulled oats was $13.36 \mathrm{~g}$, with statistically higher average in 2007 (Table 5). Zvolen and Detvan displayed statistically higher test weights compared with other analysed oat varieties (Table 6). Positive relationship between $\beta$-D-glucan and the final weight of grain was observed by Savin \& Molina-Cano (2001). Similar results were also detected in our study, where a positive correlation between the content of $\beta$-D-glucan and test weight $\left(r=0.878^{*}\right)$ was observed. A possible explanation for this fact is that $\beta$-D-glucan in oat grain is concentrated in areas where load-bearing stresses are predicted to occur, and its metabolism could be responsible for the plant's responses to selected environmental signals (Hoson 1998). Therefore, this polysaccharide can protect the plant against physiological stresses, thus resulting in better agronomical parameters, such as yield or test weight.

Generally, $\beta$-D-glucan content and test weight were higher in naked oats and grain yield and thousand grains weight in hulled oats. Higher temperature and lower precipitation in 2007 resulted in higher thousand grains weight and test weight in both oat varieties, as well as higher grain yield in naked oats. On the other hand, higher $\beta$-D-glucan content was detected in 2008 in both analysed oat groups and grain yield in hulled oats (Tables 5 and 6 ).

$\beta$-D-glucan, Se and thiamine contents in oat varieties differed according to field location and year of harvest (Hietaniemi et al. 2000). In oat varieties of yellow and white type of grain, $\beta$-D-glucan and thiamine contents were influenced by genotype; however, Se content was affected by environmental conditions.

\section{CONCLUSION}

Four oat varieties were evaluated using five experimental fertilisation treatments containing $\mathrm{N}$ and Se. Hulled and naked oats responded differently in content of $\beta$-D-glucan, grain yield, thousand grains weight and test weight. In hulled oats, the content of $\beta$-D-glucan was influenced only by the fertiliser, and the addition of Se to $\mathrm{N}$ fertiliser significantly increased the content of $\beta$-D-glucan. In naked oats, the content of $\beta$-D-glucan was higher compared with hulled oats, and was significantly affected only 
by cultivar. Grain yield was significantly influenced in hulled oats by cultivar, and in naked oats by the year, fertiliser, and cultivar. Thousand grains weight and test weight in both oat varieties were influenced by year of cultivation and cultivar, whereby, according to our results, the warmer and drier climate in 2007 caused significantly higher grain yield in naked oats, and thousand grains weight and test weight in both, hulled and naked oats.

Acknowledgements: This work was made possible, thanks to the support within Operational Programme Research and Development for the project: "Transfer, use and dissemination of research results of plant genetic resources for food and agriculture" (ITMS: 26220220058), cofinanced from the resources of the European Union Fund for Regional Development, and Vega1/0591/13 financed by the Scientific Agency of the Ministry of Education, Science, Research and Sport, and the Slovak Academy of Sciences of the Slovak Republic.

\section{REFERENCES}

ANDERSSON, A. - BÖRJESDOLTER, D. 2011. Effects of environment and variety on content and molecular weight of $B$-glucan in oats. In Journal of Cereal Science, vol. 54, no. 1, pp. 122-128.

DAOU, CH. - ZHANG, H. 2012. Oat beta-glucan: Its role in health promotion and prevention of diseases. In Comprehensive Reviews in Food Science and Food Safety, vol. 11, no. 4, pp. 355-365.

DUMA, M. - KARKLINA, D. 2008. Selenium and changes on amino acids content in germinated barley grains [on line], [cited: 2011-04-22]. Available from $<$ http:// nufb.1lu.1v/conference/foodbalt/2008/FoodbaltProceedings-2008-25-29.pdf $>$.

EUROLA, M. - EKHOLM, P. - YLINEN, M. KOIVISTOININEN, P. - VARO, P. 1990. Effects of selenium fertilizations on the selenium content of cereal grains, flour and bread produced in Finland. In Cereal Chemistry, vol. 67, no. 4, pp. 334-337.

EHRENBERGEROVÁ, J. - BŘEZINOVÁ BELCREDI, N. PSOTA, V. - HRSTKOVÁ, P. - CERKAL, R. - NEWMAN, C.W. 2008. Changes caused by genotype and environmental condition in beta-glucan content of spring barley for dietetically beneficial human nutrition. In Plant Foods for Human Nutrition, vol. 63, pp. 111-117.

FAN, M. - ZHANG, Z. - WANG, F. - LI, Z. - HU, Y. 2009 Effect of nitrogen forms and levels on $\beta$-glucan accumulation in grains of oat (Avena sativa L.) plants. In Journal of Plant Nutrition and Soil Science, vol. 172, no. 6, pp. 861-866.
GUILLON, F. - TRANQUET, G. - QUILLIEN, L. UTILLE, J-P. - ORDAZ, J.J. - SAULNIER, L. 2004. Generation of polyclonal and monoclonal antibodies against arabinoxylans and their use for immunocytochemical location of arabinoxylans in cell walls of endosperm of wheat. In Journal of Cereal Science, vol. 40, pp. 167-182.

HARTIKAINEN, H. 2005. Biogeochemistry of selenium and its impact on food chain quality and human health. In Journal of Trace Elements in Medicine and Biology, vol. 18 , no. 4, pp. 309-318.

HAVRLENTOVÁ, M. - BIELIKOVÁ, M. - MENDEL, L. KRAIC, J. - HOZLÁR, P. 2008. The correlation of (1-3) (1-4)-beta-D-glucan with some qualitative parameters in the oat grain. In Agriculture (Pol'nohospodárstvo), vol. 54 , no. 2 , pp. $65-71$.

HAVRLENTOVÁ, M. - PETRULÁKOVÁ, Z. BURGÁrovÁ, A. - GAGO, F. - HLINKOVÁ, A. - ŠTURDÍK, E. 2011.Cereals beta-glucans and their significance for the preparation of functional foods - a review. In Czech Journal of Food Sciences, vol. 29, no. 1 , pp. $1-4$.

HIETANIEMI, V. - SAASTAMOINEN, M. - KANGAS, A. - RANTANEN, O. - KONTTUR, M. 2000. $\beta$-glucan, thiamine and selenium contents in oats cultivated in Finland. [on line], [cited: 2011-04-22]. Available from <http://wheat.pw.usda.gov/ggpages/Oats/IOC6. html\#chen.

HOSON, T. 1998. Apoplast as the site of response to environmental signals. In Journal of Plant Research, vol. 111, 1998, pp. 167-177.

HUMPHREYS, D.G. - MATHER, D.E. - SMITH, D.L. 1994. Nitrogen-Fertilizer and seeding date induced changes in protein, oil and beta-glucan content in four oat cultivars. In Journal of Cereal Science, vol. 20 , no. 3, pp. 293-290.

KONUKLAR, G. - INGLETT, G.E. - WARNER, K. CARRIÉRE, C.J. 2004. Use of a $\beta$-glucan hydrocolloidal suspension in the manufacture of low-fat Cheddar cheeses: textural properties by instrumental methods and sensory panels. In Food Hydrocolloid, vol. 18, no. 4, pp. 535-545.

KOVÁČIK, P. 1997. Rozbory pôd, rastlín, hnojív a výpočet dávok živín k pol'ným a záhradným plodinám, 1. vyd. Nitra : SPU, 1997. ISBN 80-7137-358-9.

LIATIS, S. - TSAPOGAS, P. - CHALA, E. DimosthenOPOULOS, C. 2009. The consumption of bread enriched with beta-glucanreducesLDL-cholesterol and improves insulin resistance in patients with type 2 diabetes. In Diabetes and Metabolism, vol. 35, no. 2 , pp. $115-120$.

MAY, W.E. - MOHR, R.M. - LAFOND, G.P. - JOHNSTON, A.M. - STEVENSON, F.G. 2004. Effect of nitrogen, seeding date and cultivar on oat quality and yield in the eastern Canadian prairies. In Canadian Journal of Plant Science, vol. 84, no. 4, pp. 1025-1036.

McCLEARY, B.V. 2011. Megazyme Mixed-linkage beta-glucan assay procedure (McCleary method), 1.edition Bray: Bray Business Park, 2011.

MICHALÍK, I. - UŽÍK, M. - URMINSKÁ, D. ŽOFAJOVÁ, A. 2007. The effect of variety and nitro- 
gen fertilization on protein content and composition of oat grain. In Agriculture (Pol'nohospodárstvo), vol. 53, no. 4, pp. 175-182.

OSCARSSON, M. - ANDERSSON, R. - OLOFSSION, S. - JONSSON, A. 1998. Effect of cultivar, nitrogen fertilization tare and environment on yield and grain quality of barley. In Journal of Science Food Agriculture, vol. 78, no. 3, pp. 359-366.

PENNANEN, A. - XUE, T. - HARTIKAINEN, H. 2002. Protective role of selenium in plant subjected to severe UV irradiation stress. In Journal of Applied Botany, vol. 76 , no. $1-2$, pp. 66-76.

PETERSON, D.M. - WESENBERG, D.M. - BURRUP, D.E. 1995. $\beta$-glucan concentration and its relationship to agronomic characteristics in elite oat germplasm. In Crop Science, vol. 35, no. 4, pp. 965-970.

REDAELlI, R.- Del FRATE, V. - BELlATO, S. RERRACCIANO, G. - CICCORITTI, R. - GERMELER, CH. U. - De STEFANIS, E. - SGRUlletTA, D. 2013. Genetic and environmental variability in total and soluble $\beta$-glucan in European oat genotypes. In Journal of Cereal Science, vol. 57, no. 2, pp. 193-199.

SAASTAMOINEN, M. - HIETANIEMI, V. - PIHLAVA, J.M. - EUROLA, M.- KONTTURI, M. - TUURI, H. - NISKANEN, M. - KANGAS, A. 2004. Beta-glucan contents of groats of different oat cultivars in official variety, in organic cultivation, and in nitrogen fertilization trials in Finland. In Agricultural and Food Science, vol. 13, no. 1-2, pp. 68-79.

SAVIN, R. - MOLINA-CANO, J.L. 2001. Changes in malting quality and its determinants in response to abiotic stresses. Barley Science: Recent Advances from Molecular Biology to Agronomy of Yield and Quality. London, England : Haworth Press, 2001. 544 pp. ISSN 1091-1367.

TOSH, S.M. - BRUMMER, Y. - WOLEVER, T.M.S. WOOD, P.J. 2008. Glycemic response to oat bran muffins treated to vary molecular weight of $\beta$-glucan. In Cereal Chemistry, vol. 85, no. 2, pp. 211-217.

WHANGER, P.D. 2002. Selenocompounds in plants and animals and their biological significance. In Journal of American College of Nutrition, vol. 21, no. 3, pp. 223-232.

ZHANG, G.P. - WANG, J.M. - CHEN, J.X. - DING, S.R. 2001. Cultivar and environmental effects on $\beta$-glucan and protein content in malting barley. In Journal of Cereal Science, vol. 34, no. 3, pp. 295-301.

ZHANG, G. - WANG, J. - CHEN, J. - YIN, CH. - DING, S. 2002. The variation of $\beta$-glucan and protein content in barley as affected by agronomic practices. In Agricultural Sciences in China, vol. 10, no. 1, pp. 1162-1167.

ZHAO, H.-F. - LUAN, Y.-F. - FENG, X.-B. 2008. Effect of different agronomic factors on $\beta$-glucan content in Tibetan spring naked barley. In Journal of Triticeae Crops, vol. 5, pp. 512-516.

ZHOU, Q.-P. - JIA, Z.-F. - HAN, Z.-L. - YAN, H.-B. 2008. Effects of nitrogen and phosphorus on seed yield and $\beta$-glucan content of naked oat. In Plant Nutrition and Fertilizer Science, vol. 5, pp. 512-516.

Received: July 15 th, 2013 